\title{
CONCEPT OF INTEGRATED AIRBORNE SYSTEMS FOR PROVIDING AIRCRAFT OPERATIONS SAFETY, INCLUDING SYSTEMS FOR MONITORING THE FUNCTIONAL STATE OF THE OPERATOR
}

DOI: |0.36724/2072-8735-2020-|4-|2-58-65

Dmitry S. Koptev,

Southwest State University, Kursk, Russia, d.s.koptev@mail.ru

Ivan E. Mukhin, JSC "Aviaavtomatika named after V. Tarasov", Kursk, Russia
Manuscript received 28 September 2020; Accepted 10 November 2020

Keywords: aircraft, flight safety, diagnostics and prognostics of technical condition, forecast of remaining life, pilot, functional state

The development of modern civil and military aircraft is characterized by a rapid increase in the degree of functionality due to the requirements of today and the expansion of the scope of tasks to be solved. In military aviation, this feature is due to a significant expansion of the area of combat employment in terms of the enemy's active opposition, and in civil aviation, it can be explained by a largescale implementation of technical means of flight control automation and landing under the conditions of high flights traffic in urban areas. In this regard, there was a fundamentally important transition from the separate design of airframes and components to the design of aircraft systems (AS) which represent a single complex system that solves many interdependent and interrelated tasks. Of course, such systems need technical diagnostics, real-time performance testing, and forecasting the remaining resource. This paper presents and describes the main scientific and technical ways to develop and create integrated airborne systems for providing flight safety of aircraft, including systems for monitoring the functional state of the pilot. The article considers the main methods and means for diagnostics and prognostics of the technical condition of an airframe and the critical units of aircraft. Their comparative analysis is carried out and a block diagram of an integrated diagnostic system is proposed. The essence of this system is to implement the procedure for accumulating flight data on the parameters of critical components and units on board aircraft and using a rapid-analysis method that involves monitoring the dynamics of changes in the trend of the controlled parameters in relation to limit values in real-time mode.

Information about authors:

Dmitry S. Koptev, Lecturer of Space Instrument Engineering and Communication Systems Department, Southwest State University, Kursk, Russia Ivan E. Mukhin, Doctor of Engineering, Senior Research Associate, Investment Projects General Designer of JSC "Aviaavtomatika named after V. Tarasov", Kursk, Russia

\footnotetext{
Для цитирования:

Коптев Д.С., Мухин И.Е. Концепция разработки комплексных бортовых систем обеспечения безопасности полётов воздушных судов, включая системы контроля функционального состояния оператора // Т-Сотm: Телекоммуникации и транспорт. 2020. Том I4. № 12. С. 58-65.
}

For citation:

Koptev D.S., Mukhin I.E. (2020) Concept of integrated airborne systems for providing aircraft operations safety, including systems for monitoring the functional state of the operator. T-Comm, vol. 14, no.12, Pp. 58-65. (in Russian) 


\section{Introduction}

At present, within the state program of the Russian Federation "Development of the aviation industry for 2013-2025" integrated airborne systems for providing flight safety of aircraft are currently being designed to solve these problems. Those systems, in addition to technical diagnostics and prognostics of critical components of aircraft, include means for continuous diagnostic monitoring of the functional state of the pilot's health when performing professional functions. The goal of the paper is to present the basic principles of design concept of such systems.

\section{Materials and research methods.}

An integrated airborne flight safety system is designed to collect data from aircraft components' and assemblies' condition sensors, as well as from sensors for monitoring the functional state of the pilot. Then this system is to process data on board making dynamic correlations between parameter values in all flight phases, automatically compare data obtained with limit values, and transmit diagnostic information to ground control stations by means of aircraft communications. The block and functional diagram of an integrated airborne flight safety system is shown in Figure 1.

Such a system is built on a modular principle with an open architecture for maximum simple possible adaptation to various types of aircraft. The system must have two modes of operation: operating and built-in control. In the first mode, the system performs all basic functions. In the second case, it continuously monitors its own performance with a fault detection probability of at least 0.9 [1].

In more detail, the proposed integrated flight safety system for future-technology aircraft with AFDX and Ethernet digital lines on board is shown in Figure 2.

The diagnostic data collecting unit (BSDI) provides conversion, collection and transmission of signals from vibration sensors installed in the controlled nodes and elements of aircraft over the Ethernet channel.
The report rate of these sensors varies from $64 \mathrm{~Hz}$ to $15 \mathrm{kHz}$, depending on the indicator being diagnosed. The number of vibration sensors depends on the layout of aircraft, as well as the geometry of the controlled units' placement.

The diagnostics and prognostics unit (BDIP) provides the calculation of diagnostic and prognostic indicators using specified algorithms adapted to a specific type of aircraft. The initial information for initializing algorithms comes via an Ethernet channel from the BSDI unit. Information in digital form via the AFDX channel comes from live monitoring and recording system (SOK), on-board automated control system (BASK), crash recorder, as well as regular aircraft sensors. Depending on the flight mode and the received information from the sensors, the data processed by the unit is transmitted during the flight via an Ethernet channel to the on-board communication unit (BBS), onboard flight data recorder system and ground processing facility (NKO).

During the flight, BDIP transmits warning information of an emergency nature via an AFDX channel to a multi-function display for emergency decision-making by an aircraft commander. If the maximum permissible values of flight parameters are critically exceeded, BDIP unit sends a signal to activate an emergency location transmitter [1].

BBS unit is purposed to transmit limited on-board information via broadband and narrow-band radio access channels to a remote ground control center directly during the flight, as well as to transmit all registered flight information via a wireless broadband channel to a ground processing station in the area of airfield.

In accordance with the recommendations of the center for aviation and space medicine in BKSP unit, the following physiological indicators of the pilot's health should be diagnosed in real time mode: the level of peripheral blood saturation, pulse and respiratory rate, and heart rate variability.

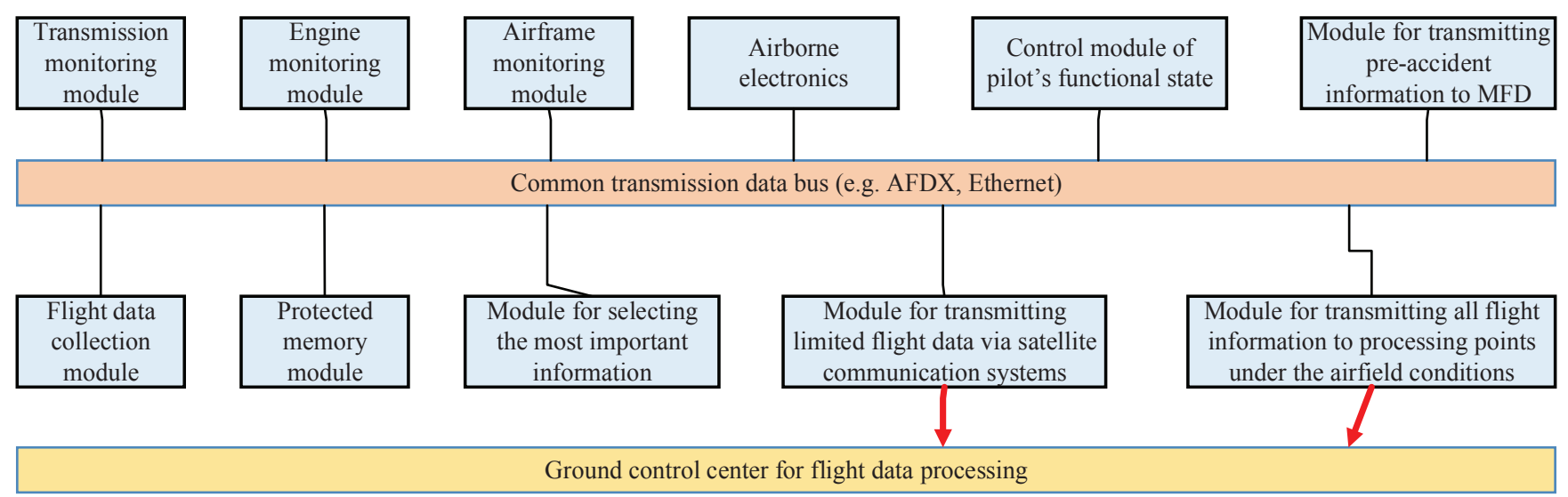

Figure 1. Block and functional diagram of integrated system for diagnostics and prognostics of aircraft technical condition, including the subsystem for monitoring the functional state of the pilot 


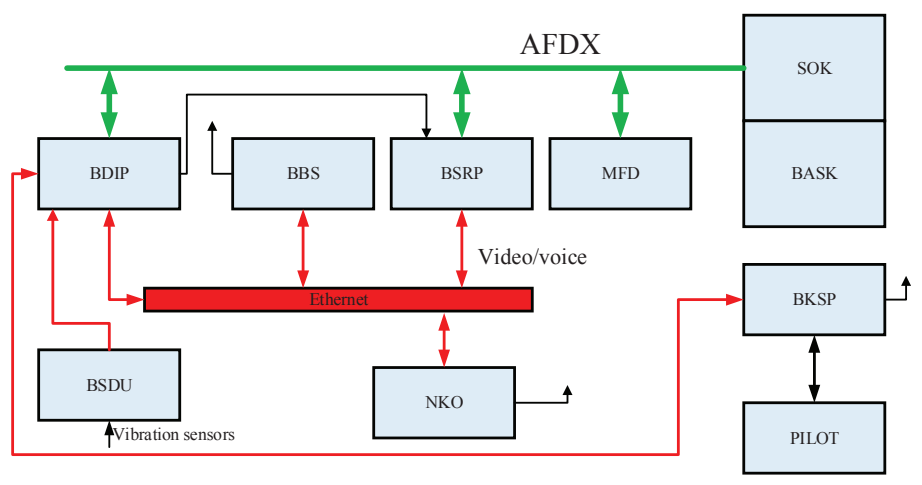

Figure 2. Block diagram of integrated flight safety system with an AFDX bus:

BDIP - diagnostics and prognostics unit; BSDI - diagnostic data collecting unit; BBS - on-board communication unit; BSRP - on-board

flight data recorder system; NKO - ground processing facility;

SOK - live monitoring and recording system; BASK - on-board automated control system; MFD - Multi-Functional Display;

BKSP - pilot's state monitoring unit

The following tasks must be solved to implement the concept of an integrated airborne flight safety system:

1) electing the types, number, installation locations and orientation of sensors on board aircraft;

2) e ablishing dynamic correlations between the controlled parameters of aircraft and developing their processing technology on a real time basis in all phases of the flight with the opportunity to warn a pilot about the upcoming pre-accident situation;

3) developing a subsystem for monitoring the functional state of the pilot, defining the minimum necessary set of diagnostic parameters, their contactless removal, processing and recording by means of on-board units of storing and transmitting data;

4) veloping algorithms for the operation of diagnostics and prognostics system of technical condition of aircraft;

5) dev oping a system for remote transmission of flight information via satellite and/or mobile communication systems in real-time mode, including warning signals for control centers about a pre-emergency situation on-board;

6) ensuring the transmission of the full volume of flight information to ground control stations under airfield conditions.

\section{Results and discussion.}

In the given paper, we consider in detail the structure and principles of operation of the main subsystems of the integrated airborne flight safety system. The block diagram of the system for diagnosing the stress-strain behavior of an airframe and critical components is shown in Figure 3.

The accumulation of data on the technical condition of aircraft is carried out with the help of fiber optic subsystems with distributed Bragg cells, allowing to control the stress-strain behavior of aircraft nodes in particular points of the airframe listed in the map of aircraft stresses. The accumulation of data is also carried out by means of fiber optic subsystems, based on the Doppler effect in order to have the possibility to detect the occurrence of cracks and plastic deformations in a wider area than the cells of Bragg. These sensors inspect the controlled technical nodes and transmit data to the communication unit, where they are collected and sent to the flight data recorder, as well as to ground control centers, where, through eddy current methods, a decision is made on permitting a pilot to operate in the next flight [2].

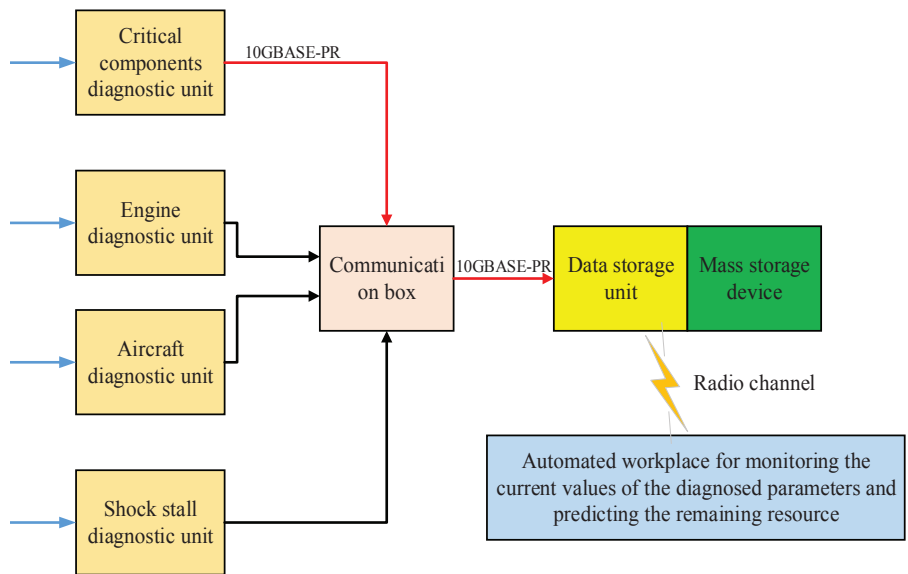

Figure 3. Block diagram of the stress-strain behavior diagnostics system for a helicopter

In addition, high-performance computing tools for ground control based on constantly accumulated flight statistics should determine the moving velocity of a multidimensional vector of parameters towards the boundaries of the hypercube of allowable values. The moving velocity analysis of the multidimensional vector will allow ground services to determine the time interval during which the safe operation of aircraft is possible.

The subsystem for diagnostics of the stress-strain behavior of an aircraft airframe consists of signal converter units from fiberoptic Bragg cells and sets of fiber-optic sensors.

The sensitive element of all fiber-optic sensors (VOD) is Fiber Bragg Gratings (FBG).

FBG is a structure with a periodic change in the refraction index along its length, being formed in the core of optical fiber. FBG has a narrow reflection spectrum, resonant wavelength $\left(\lambda_{0}\right)$ which depends on the period of refraction index $(d)$.

The spectral characteristics of fiber-optic Bragg gratings (FBG) are of resonant nature, but the "wavelength-amplitude" transformation function for their evaluation in the resonance region either oscillates or has a rather flat or nonlinear character. Therefore, in order to increase the resolution power of measurements, FBG with inhomogeneities in the spectrum or FBG with a special form of spectrum are synthesized to provide linearization of measurement characteristics. Currently, in the structure of fiber-optic sensors, FBG with concave, triangular symmetrical and asymmetric spectral forms are being developed.

In case of an external mechanical action on FBG there changes the period of refraction index $(\Delta d)$, which leads to a change in FBG resonant wavelength $(\Delta \lambda)$. The main purpose of converter units is to measure the shift of FBG resonant wavelength of each sensor and make the stress-strain analysis according to this data. Since FBG is sensitive to temperature changes, there are two types of sensors in each set: fiber-optic strain sensors (VOD) and fiber-optic thermal compensation strain sensors (VODD-T). VODD-T is insensitive to deformation of the monitoring object and is only affected by changes in the temperature of it. These changes of VODD-T resonant wavelength allow us to determine the deformation component of VODD sensor wavelength change as the difference of shifts of VODD and VODD-T sensors resonant wavelengths [3-5].

The main components of the units are identical, both units consist of a tunable erbium fiber laser (TEFL), detection module (DM) (4 DM in PDP unit and 1 DM in PSS unit), switch unit 
(BK), power supply unit (BP) and temperature control unit (TCU). BP provides electrical power for the main modules of the unit (BK, DM, TEFL) with a voltage of $5 \mathrm{~V}$. TCU maintains the set temperature mode of the main unit modules by controlling the heaters and Peltier elements located on these modules, and controls the power supply unit, including the main modules after setting the required temperature mode in them. TEFL is a source of optical radiation and carries out the scanning of VOD lines. DM provides reception of optical signals reflected from FBG and calculates strains and stresses for the monitoring object. BK provides interaction and synchronization of TEFL module with DM, as well as data transfer to external interfaces. The block diagram of a tunable erbium fiber-optic laser is shown in Figure 4.

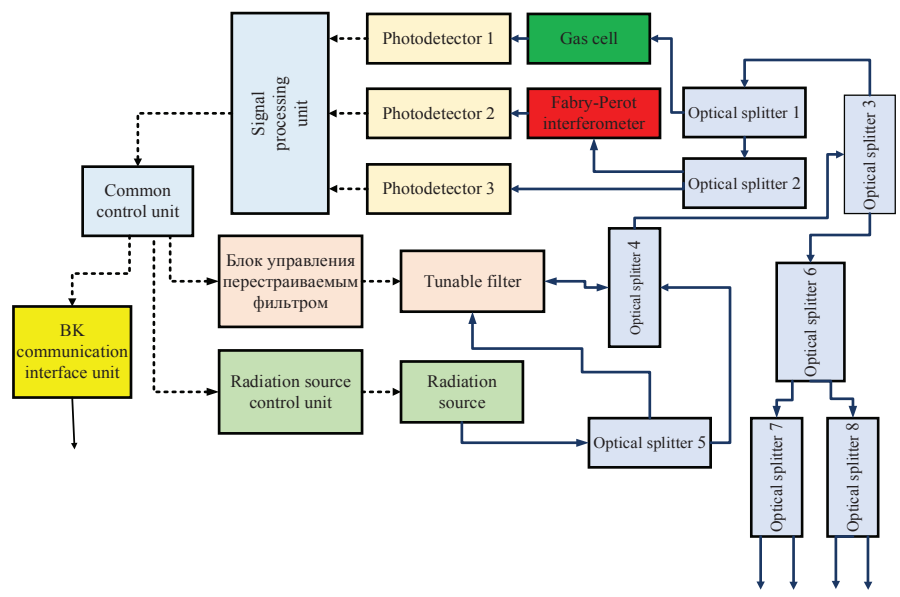

Figure 4. Block diagram of TEFL (the dashed line shows electrical interactions, the solid line - optical ones)

The main task of TEFL is to scan the optical line of fiberoptic sensors. TEFL changes the wavelength of radiation by scanning in the wavelength range from 1510 to $1590 \mathrm{~nm}$ at a frequency of $100 \mathrm{~Hz}$. The change in the radiated wavelength is carried out in a tunable filter by changing the gap between two dielectric mirrors. The travel velocity of one of the mirrors determines scanning frequency. At the output of the ring resonator (optical splitter 4), radiation enters optical splitter 3, after which $90 \%$ of power goes to output splitters $(6,7$ and 8$)$, which divide the signal into 4 independent optical channels. The remaining part of radiation is separated (by means of optical splitters 1 and 2) and enters a wavelength locker based on the Fabry-Perot interferometer and a gas cell. The transmission spectrum of a gas cell is a spectrum with obvious absorption peaks that correspond to strongly defined wavelengths $\left(\lambda_{1}\right)$ and do not depend on external influences (Figure 5).

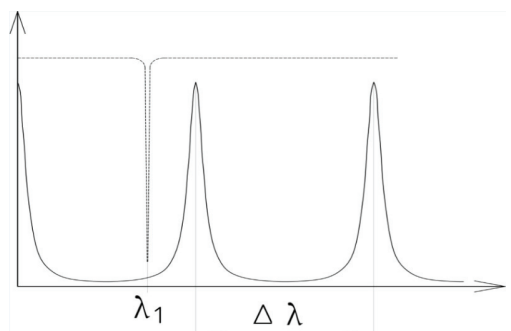

Figure 5. Transmission spectrum of Fabry-Perot interferometer (the solid line) and one of the absorption peaks of the gas cell (the dashed line)
Scanning radiation passes through a gas cell and is absorbed at certain wavelengths, which is detected by photodetector 1 . This allows one to obtain an accurate absolute value of TEFL wavelength when the radiated wavelength passes through the absorption peaks. The spectrum of Fabry-Perot interferometer is a set of peaks with a predefined distance between peaks $(\Delta \lambda)$, determined during the manufacture of this element. Photodetectors 2 and 3 allow obtaining a spectral picture of the interferometer.

Data from the photodetectors is digitized and continuously transmitted to the database (Figure 10). BK receives information from TEFL in the form of the coordinates of each peak of FabryPerot interferometer on the time scale. The absolute value of each peak wavelength is determined at the stage of calibration of TEFL module and loaded as a table in BK [6-8].

The block diagram of BK is shown in Figure 6.

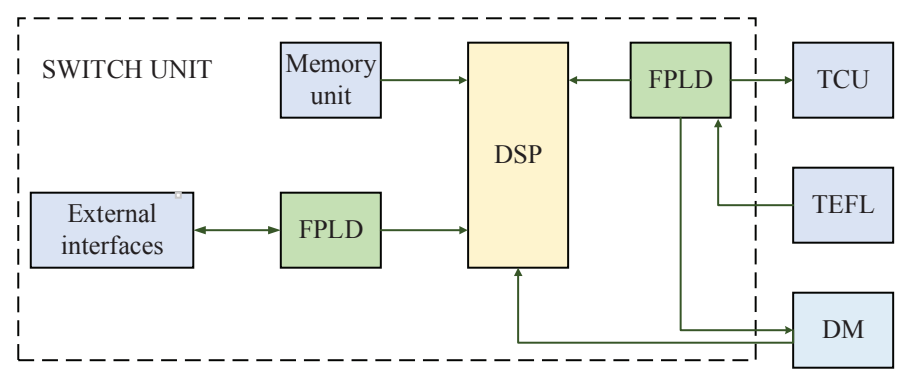

Figure 6. Block diagram of switch unit (BK)

The switch unit (BK) provides:

- $\mathrm{s}$ nchronization of TEFL module with detection modules (DM);

- data exchange with DM (via Ethernet technology);

- storage of calibration and configuration data;

- data exchange with external interfaces;

- ransfer of data on the temperature and operation of all modules to the temperature control unit (TCU);

- generation of control signals for DM.

The general block diagram of the detection module is shown in Figure 7.

In total, 15 optical splitters are installed in DM, the 7 of which provide separation of input optical radiation of TEFL into 8 channels (optical splitters $1 . . .7$ ), and the 8 other splitters (optical splitters $8 \ldots 15$ ) provide output of the signal reflected from fiber sensors from the line to the photodetector. The optical signal from each channel gets to the photodetector, where it is converted into an electric one, then after being amplified, it gets to $\mathrm{AD}$ encoder. DM board has four two-channel AD encoders, the outputs of which are connected to FPLD with a clock frequency of $12.5 \mathrm{MHz}$. Data from these channels is transmitted to a digital signal processor (DSP) for processing.

The general block diagram of signal transmission, conversion, and reception is shown in Figure 8.

Tunable source (TEFL) (Figure 12) continuously changes the wavelength of radiation in the range from 1510 to $1590 \mathrm{~nm}$ per one scanning cycle. The radiation is divided into 8 identical streams (to provide the scanning of 32 channels using 4 DM) due to optical splitters installed in DM. 


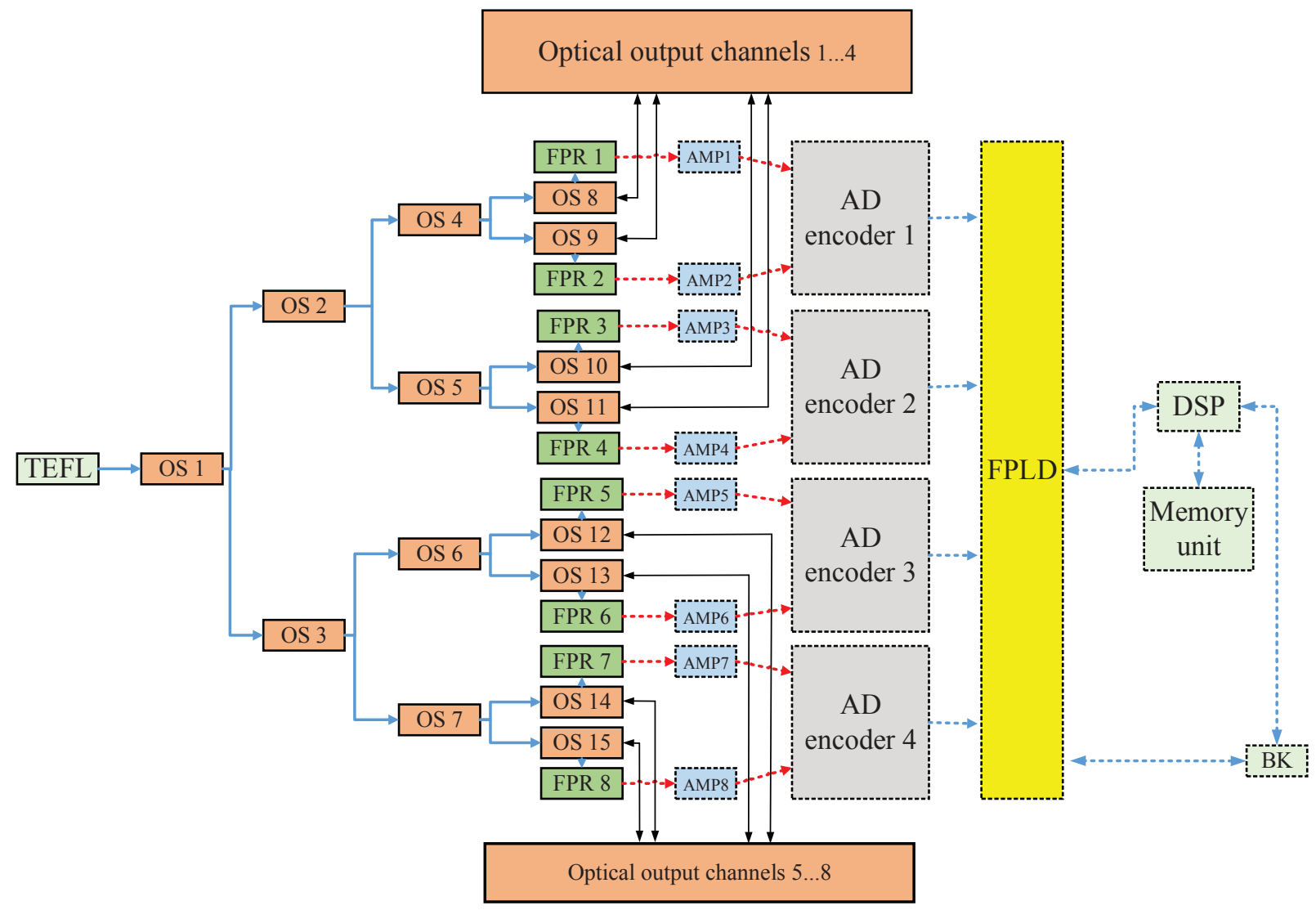

Figure 7. Block diagram of DM (the dashed line - electrical interactions, the solid line - optical ones):

OP - optical splitter; FPR - photodetector; AMP - amplifier

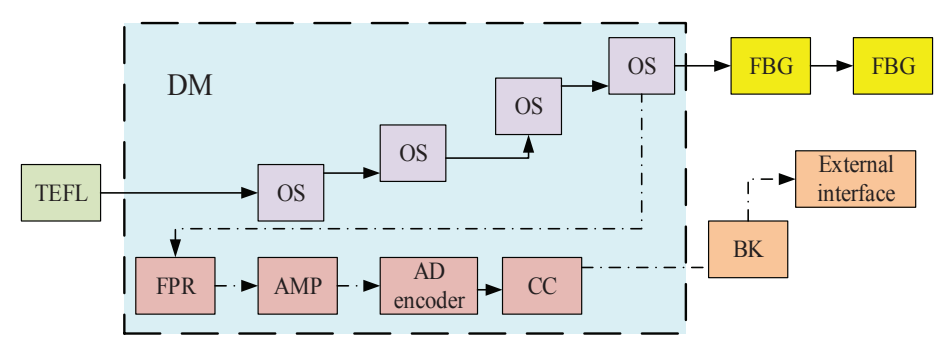

Figure 8. Block diagram of the process of signal transmition, conversion and reception:

OP - optical splitter; FPR - photodetector; AMP - amplifier; $\mathrm{CC}$ - calculator; BK - switch unit

Passing along the optical line, radiation reaches the line of sensors based on FBG. The main feature of FBG is selective reflection of a certain narrow part of spectrum. If FBG resonant wavelength at a certain time coincides with the wavelength emitted by the laser, then the main volume of radiation is reflected from FBG back to the converter unit, where the optical power leap is recorded by photodetectors in DM. Knowing the current wavelength emitted by TEFL module, the system can accurately determine the current resonant wavelength of FBG by synchronizing DM and TEFL with the help of BK. Using a photodetector, the optical signal is converted into an electrical signal, amplified in the analog part of DM, and then digitized. Calculator determines the center wavelength of each sensor and computes strains by taking into account temperature balance sensors [9].

If FBG resonant wavelength does not coincide with the wavelength emitted by the laser at the current time, this radiation passes through FBG with minimal losses, allowing the next sensor in the line to be illuminated. The reflected signal from this sensor also returns to DM, where strain is calculated in the same way.

Figure 9 shows a prospective scheme of fiber-optic sensors' location being installed in a helicopter.

When monitoring the condition of helicopter's vital systems, including critical mechanical units, the ground-based complex software uses a trend and forecast control module that performs two types of trend analysis: short-term and long-term ones. Short-term trend and forecast control is performed on the basis of time series 1:

$$
\Delta P_{j \operatorname{coc}}\left(t_{1}\right), \Delta P_{j \operatorname{coc}}\left(t_{2}\right), \ldots, \Delta P_{j \operatorname{coc}}\left(t_{N}\right),
$$

where $\Delta P_{j \text { coc }}$ - difference between the current and the reference value of the controlled parameter or group (vector) of parameters that characterize the state of the system (unit) at time $t_{i}$ in the current flight when the system (unit) enters the controlled mode $j$. 


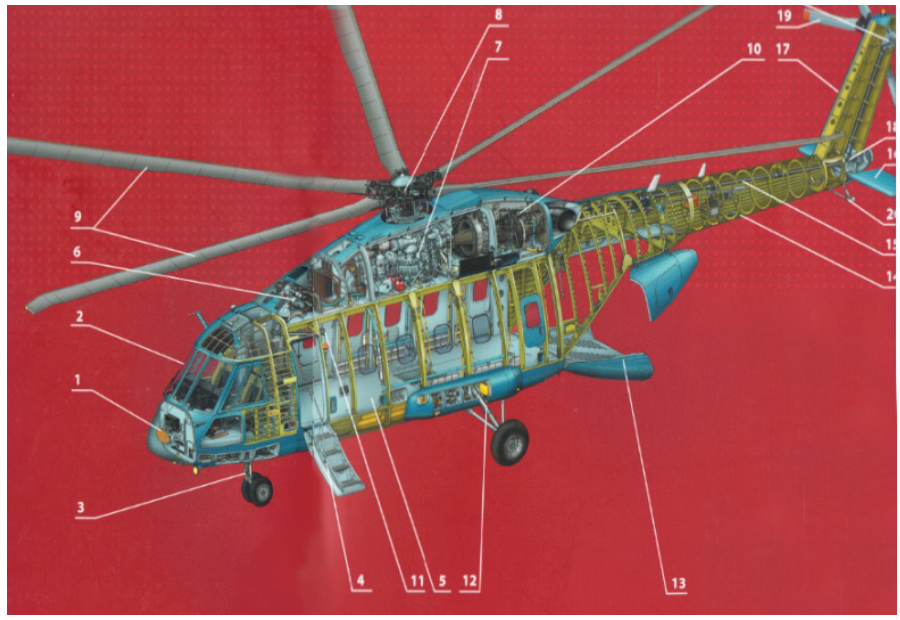

Figure 9. Prospective scheme for monitoring the technical condition of aircraft (on the example of a helicopter):

$1,3,4,11,13,17$ - fiber-optic sensors of airframe deformations; 2 - module for transmitting all flight information to processing points at the airfield; 5 - module for monitoring the pilot's psychophysical state; 6 - module for transmitting flight information via Satellite Communication System; 7, 8 - transmission monitoring sensors; 9 - rotor blades; 10 - engine monitoring sensors; 12 - airframe and landing gear monitoring module; 14 - transmission monitoring module; 15 - emergency information storage; 16 - module for transmitting information about the pre-accident state to a multi-functional display (MFD);

$$
19 \text { - steering rotor }
$$

Long term trend and forecast control is performed based on time series 2 :

$$
\Delta P_{j \operatorname{coc}}\left(t_{1}\right), \Delta P_{j \operatorname{coc}}\left(t_{2}\right), \ldots, \Delta P_{j \operatorname{coc}}\left(t_{N}\right),
$$

where $\bar{\Delta} P_{j \text { coc }}$ - ave ge change of system (unit) state parameter in mode $j$ of flight $I ; T_{\text {нар } i}$ - operating time of the system (unit) in mode $j$ of flight $i ; T_{\text {нар.тек }}$ - operating time of the unit in mode $j$ of the current flight.

In this case, the mode with the most significant trend and the worst forecast is selected as an assessment of the risk of changes in the condition of the controlled system (unit) as a whole.

The mode uses learning knowledge bases based on neural network technologies. In a situation where this module is not able to automatically make a decision on the current state of the controlled system (unit), the system of interactive dialogue with an operator (the person making the final decision) is activated. Besides, determining the characteristics of normal (reference) condition of the controlled vital system (unit) is performed according to the adaptive principle, which consists in the fact that at the initial stage of vital system (mechanical part) operation, for example, while performing the first flight it is impossible to cover all possible operation modes of the controlled system (unit), especially dynamic ones, and the full range of flight modes of a helicopter, therefore, the reference characteristics for the operation of the controlled system (mechanical unit) on the ground and in flight will not be formed for all modes. During further vital system (mechanical unit) operation, there gradually appear new regimes. Based on this, the characteristics of the reference (serviceable) state of the controlled vital (mechanical unit) must be adjusted taking into account the results of sensor measurements obtained in these new encountered modes.

The pilot health-monitoring unit, which is part of the integrated flight safety system, is designed to register the physiological indicators of the pilot's health and determine his/her general functional state. This subsystem uses a pulse oximeter module of the "clip" type to collect and transmit primary physiological information via a wired interface, and then, using the physiological parameters processing unit, converts primary signals and calculates physiological parameters, such as: pulse rate, peripheral blood saturation level and respiratory rate. The results obtained are transmitted via a wireless information interaction channel (Bluetooth) to the data collection unit, where the determined physiological parameters are stored in internal non-volatile memory, and the received data is sent to a summing and signaling unit (SSU) for transmission to a ground control center.

The general block and functional diagram of the pilot's state monitoring subsystem is shown in Figure 10.

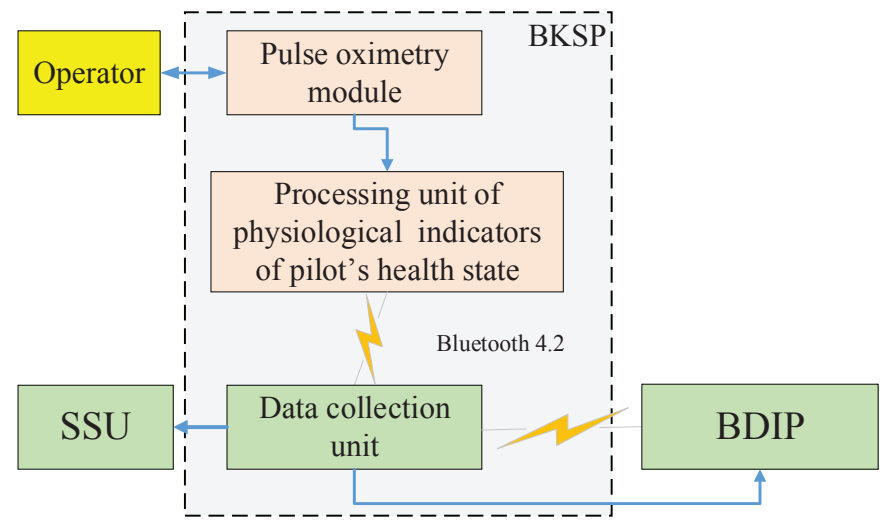

Figure 10. General block and functional diagram of the pilot's state monitoring subsystem

The technique for monitoring the physiological parameters of the pilot's health is based on a spectrophotometric method for determining the amount of oxygen connected with hemoglobin in arterial blood and tissues. The degree of saturation of hemoglobin molecules with oxygen $\left(\mathrm{SpO}_{2}\right)$ is an objective indicator of the level of oxygen supply to the pilot's body, which depends on the quality of functioning of aircraft oxygen equipment or on the partial pressure of oxygen in the respiratory mixture when flying on aircraft that are not equipped with a pressurized cabin and oxygen equipment. The physiological norm of a healthy man when breathing air is the level of $\left(\mathrm{SpO}_{2}\right) 94-98 \%$. A decrease below $90-94 \%$ indicates an insufficient amount of oxygen entering the respiratory system, and is a harbinger of the onset of hypoxia [11].

Since the change in the level of $\mathrm{SpO}_{2}$ in blood vessels and tissues is related to the pumping function of myocardium during each heartbeat, it has a pulsating character that correlates with the heart rhythm. Therefore, a pilot's state monitoring unit calculates the duration of inter-systolic intervals, which allows us to determine the current value of the pulse rate. In its turn, the amount of saturation and the duration of inter-systolic intervals depends on the depth of person's breathing. This makes it possible to accurately calculate the value of the respiratory rate. 
The measuring ranges of physiological indicators of the pilot's health condition are determined by the indicators of cardiovascular and respiratory system of a healthy person, as well as their reserve abilities of deviations from the physiological norm. If any indicator goes out of the lower or upper measuring range, it indicates the onset of diagnostically significant changes in the cardiovascular or respiratory system [10-11].

\section{Conclusion}

Thus, the major scientific and technical ways of designing and developing integrated airborne systems for providing aircraft flight safety, including systems for monitoring the functional state of the pilot have been presented and characterized. The present paper describes the main methods and means for diagnostics and prognostics of airframe technical condition and the principal units of aircraft. Their comparative analysis has been carried out and the block diagram of an integrated diagnostic system has been proposed. The purpose of this system is to implement the procedure for accumulating flight data on the parameters of critical components and aggregates on board aircraft and using a rapid-analysis method, which consists in monitoring the dynamics of changes in the trend of the controlled parameters in relation to the limit values in real-time mode. The article shows that in such a system, the presence of a warning visual and audio alarm for the crew of an aircraft about an emergency situation is a necessary condition.

It has been established that diagnostics of the stress-strain condition of an aircraft airframe should be performed by a fiberoptic subsystem with Bragg cells at the points specified in the aircraft map of strains.

It has been proved that the greatest completeness of data on the stress-strain condition of aircraft is possible when fiber-optic subsystems with distributed Bragg cells and fiber-optic systems based on recording the fact of acoustic emission are used together. Recording of acoustic emission signals should be carried out by fiber-optic rings that allow using the Doppler effect.

The most appropriate procedure for general diagnostics of aircraft should lie in the monitoring of aircraft during the flight, when there can be found "suspicious" places detected during the flight. On ground, one can conduct a more thorough examination of these "suspicious places" by using ground-based eddy current methods.

High-performance ground control facilities should be able to determine the moving velocity of a multidimensional vector of parameters to the boundaries of the hypercube of allowable values based on constantly accumulated flight statistics. Based on the velocity of the multidimensional vector, ground control centers must determine the time interval during which safe operation of aircraft is possible.

The concept of monitoring the physiological state of the pilot is based on spectrophotometric methods and has a minimum number of correlants, high information content and the ability to quickly process the results obtained on a real time basis on board aircraft. The main idea of this monitoring is to maintain a professional flight history that is accumulated over the entire professional career for each pilot individually. It is supposed that in the future, the decision to allow the pilot to fly will depend on the results of his/her personal profile analysis.

\section{References}

1. I.E. Mukhin, A.I Mukhin, S.N. Mikhailov, D.S. Koptev (2018). Methodological foundations for the synthesis of systems for diagnostics of the technical condition of space and aircraft. South-West. state un-t. Kursk. 212 p.

2. D.S. Koptev, I.G. Baban , I.E. Mukhin. (2019). The main directions of development and creation of integrated on-board systems for ensuring the safety of flights of aircraft, including systems for monitoring the physiological parameters of the pilot's health. Advances in modern radio electronics. No. 2. P. 44-53.

3. D.S. Koptev I.E. Mukhin (2019). Strategy for the development of systems for diagnostics and prognostics of the technical state of promising aircraft. Information - measuring and control systems. Vol. 17. No. 2. P. $65-70$.

4. B.Yu. Lemeshko, S. Komissarova, A.E. Shcheglov (2010). Questions of application of some criteria for checking randomness and the absence of a trend. Metrology. 2010., No. 12. P. 3-25.

5. A.A. Bo yavlenskiy (2017). Analysis of procedures for ensuring the reliability of means and methods for measuring vibration in the processes of maintaining the airworthiness of aircraft. Scientific Bulletin of MSTU GA. Vol. 20. No. 1. P. 78-87.

6. S.V. Gushchin, A.P. Polonsk (2016). Using laser control of vibration parameters in diagnostics of products of the aviation industry. Bulletin of the Irkutsk State Technical University. Vol. 20. No. 10. P. 21-27.

7. P.A. Bud , A.M. Vinogradenko, A.V. Mezhenov, A.A. Chikirev (2020). Method and device of intelligent express control of the technical condition of ground communication facilities and radio technical support of flights. Control Systems, Communications and Security. No. 1. P. 235-283.

8. D.S. Koptev I.E. Mukhin, I.G. Babanin (2019). Digital biometric complex for assessing the functional state of an aircraft pilot. Biomedical radio electronics. Vol. 22.No. 7. P. 23-31.

9. D.S. Koptev I.E. Mukhin (2019). Stages of development of systems for diagnostics and forecasting of the technical condition of promising aircraft. In the collection: Infocommunications and space technologies: state, problems and solutions, a collection of scientific articles based on the materials of the III All-Russian scientific-practical conference. Executive editor V.G. Andronov. P. 208-215.

10. I.E. Muk , D.S. Koptev (2019). Method for determining the level of peripheral blood saturation of the pilot of an aircraft in the telecommunication system of operational medical control. Telecommunications. No. 2. P. 2-10.

11. .E. Mukhin, S.L. Seleznev, D.S. Koptev (2017). Directions and practical results of the creation of methods and tools for diagnostics and prognostics of the state of the aviation complex "man-machine". Bulletin of the South-West State University. Series: Management, computer technology, informatics. Medical instrumentation. Vol. 7. No. 3 (24). P. 46-57. 


\title{
КОНЦЕПЦИЯ РАЗРАБОТКИ КОМПЛЕКСНЫХ БОРТОВЫХ СИСТЕМ ОБЕСПЕЧЕНИЯ БЕЗОПАСНОСТИ ПОЛЁТОВ ВОЗДУШНЫХ СУДОВ, ВКЛЮЧАЯ СИСТЕМЫ КОНТРОЛЯ ФУНКЦИОНАЛЬНОГО СОСТОЯНИЯ ОПЕРАТОРА
}

\author{
Коптев Дмитрий Сергеевич, Юго-Западный государственный университет, г. Курск, Россия, d.s.koptev@mail.ru \\ Мухин Иван Ефимович, АО "Авиаавтоматика" им. В.В. Тарасова", г. Курск, Россия
}

\section{Аннотация}

В данной статье приведены и охарактеризованы основные научно-технические пути разработки и создания интегрированных бортовых систем обеспечения безопасности полетов летательных аппаратов, включая системы контроля функционального состояния пилот. Рассмотрены основные методы и средства диагностики и прогностики технического состояния планера и основных агрегатов летательных аппаратов. Проведен их сравнительный анализ и предложена структурная схема интегрированной системы диагностики, суть которой заключается в реализации процедуры накопления полетных данных о параметрах ответственных узлов и агрегатов на борту летательного аппарата и применении метода экспресс-анализа, заключающегося в контроле динамики изменения тренда контролируемых параметров по отношению к предельным значениям в режиме реального времени.

Ключевые слова: летательный аппарат, безопасность полётов, диагностика и прогностика технического состояния, прогнозирование остаточного ресурса, пилот, функциональное состояние.

\section{Литература}

І. Мухин И.Е., Мухин А.И., Михайлов С.Н., Коптев Д.С. Методологические основы синтеза систем диагностики технического состояния космических и летательных аппаратов: монография; Юго-Зап. гос. ун-т. Курск, 20І8. 212 с.

2. Коптев Д.С., Бабанин И.Г., Мухин И.Е. Основные направления разработки и создания интегрированных бортовых систем обеспечения безопасности полётов летательных аппаратов, включая системы контроля физиологических параметров здоровья пилота // Успехи современной радиоэлектроники. 2019. №2. С. 44-53.

3. Коптев Д.С., Мухин И.Е. Стратегия разработки систем диагностики и прогностики технического состояния перспективных летательных аппаратов // Информационно-измерительные и управляющие системы. 2019. Т.І7. №2. С. 65-70.

4. Лемешко Б.Ю., Комиссарова А.С., Щеглов А.Е. Вопросы применения некоторых критериев проверки случайности и отсутствия тренда // Метрология. 2010. № 12. С. 3-25.

5. Богоявленский А.А. Анализ процедур обеспечения достоверности средств и методов измерения вибрации в процессах поддержания лётной годности воздушных судов // Научный вестник МГТУ ГА. 20І7. Т. 20. № I. С. 78-87.

6. Гущин С.В., Полонский А.П. Использование лазерного контроля параметров вибрации при диагностике изделий авиационной отрасли // Вестник Иркутского государственного технического университета 2016. Т. 20. №10. С. 2I-27.

7. Будко П.А., Винограденко А.М., Меженов А.В., Чикирев А.А. Способ и устройство интеллектуального экспресс-контроля технического состояния наземных средств связи и радиотехнического обеспечения полётов // Системы управления, связи и безопасности 2020. № І. С. 235-283.

8. Коптев Д.С., Мухин И.Е., Бабанин И.Г. Цифровой биометрический комплекс оценки функционального состояния пилота воздушного судна // Биомедицинская радиоэлектроника. Т. 22. № 7. 2019. С. 23-3І.

9. Коптев Д.С., Мухин И.Е. Этапы разработки систем диагностики и прогностики технического состояния перспективных летательных аппаратов. В сборнике: Инфокоммуникации и космические технологии: состояние, проблемы и пути решения, сборник научных статей по материалам III Всероссийской научно-практической конференции. Ответственный редактор В.Г. Андронов. 2019. С. 208-215.

І0. Мухин И.Е., Коптев Д.С. Метод определения уровня периферической сатурации крови пилота воздушного судна в телекоммуникационной системе оперативного медицинского контроля // Телекоммуникации. 2019. №2. С. 2-10.

ІІ. Мухин И.Е., Селезнев С.Л., Коптев Д.С. Направления и практические результаты создания методов и средств диагностики и прогностики состояния авиационного комплекса "человек - машина" // Известия Юго-Западного государственного университета. Серия: Управление, вычислительная техника, информатика. Медицинское приборостроение. 2017. Т. 7. № 3 (24). С. 46-57.

Информация об авторах:

Коптев Дмитрий Сергеевич, преподаватель кафедры космического приборостроения и систем связи, Юго-Западный государственный университет, г. Курск, Россия

Мухин Иван Ефимович, д.т.н., старший научный сотрудник, генеральный конструктор по инвестиционным проектам АО "Авиаавтоматика" им. В.В. Тарасова", г. Курск, Россия 